\title{
Communication
}

[Comunicação]

\section{Digestibility of dry extruded food in adult dogs and puppies}

\author{
[Comparação da digestibilidade de um alimento seco extrusado entre cães adultos e filhotes] \\ C.P. Zanatta ${ }^{1}$, A.P. Félix², C.B.M. Brito ${ }^{3}$, F. Murakami ${ }^{2}$, T.T. Sabchuk ${ }^{1}$, \\ S.G. Oliveira ${ }^{4 *}$, A. Maiorka ${ }^{4}$ \\ ${ }^{1}$ Aluno de graduação - UFPR - Curitiba, PR \\ ${ }^{2}$ Aluno de pós-graduação - UFPR - Curitiba, PR \\ ${ }^{3}$ Laboratório de Nutrição animal - UFPR - Curitiba, PR \\ ${ }^{4}$ Departamento de Zootecnia - UFPR - Curitiba, PR
}

The pet food market has expanded considerably over the last few years. However, this expansion has raised some doubts regarding the quality of the products offered in the market. Therefore, knowing the digestibility of dog food is essential to supply these animals with adequate nutrients to provide their requirements in every physiological stage, particularly in terms of energy.

The aging process in cats and dogs is mainly influenced by genetics, nutrition, and the environment to which the animals are submitted, among other factors. Animal development is associated to changes in the physiological and metabolic systems; however, such changes are not completely elucidated in companion animals (Hayek and Davenport, 1998). As animal's age, the intestinal microbiota and morphology, as well as the production of digestive enzymes and hormones are modified, influencing digestibility (Fahey et al., 2008). According to Meyer et al. (1940), amylase, trypsin, and lipase activities in the duodenal juice are reduced with age. However, Gilham et al. (1993), in a study with Labrador Retriever puppies with twelve or twenty weeks of age, did not find any statistically significant influence of age on nutrient digestibility. Taylor et al. (1995) also postulated that the reduction of enzyme production as a consequence of age does not affect nutrient digestion and absorption because the mammalian gastrointestinal tract (GIT) has a

Recebido em 23 de dezembro de 2009

Aceito em 23 de março de 2011

*Autor para correspondência (corresponding author)

E-mail: sgoliveira@ufpr.br large reserve capacity, allowing sufficient time for the action of digestive juices on the food, thereby compensating the lower enzymatic activity in older animals.

In order to contribute to the understanding of the effect of aging on food digestibility in dogs, the objective of the present study was to compare apparent digestibility coefficients of dry extruded dog food between adult dogs and puppies.

Twelve Beagles, distributed in six adults (5 years of age) and six puppies (5-6 months of age) and three males and three females per age group, were used. Adults and puppies weighed, in average, $13.4 \pm 1.7 \mathrm{~kg}$ and $6.5 \pm 0.6 \mathrm{~kg}$, respectively. Dogs were housed in metabolic cages $(0.7 \mathrm{~m}$ long $\mathrm{x} 0.6 \mathrm{~m}$ wide $\mathrm{x} 0.5 \mathrm{~m}$ high), and fed a dry extruded food, with nutritional content exceeding the minimum recommendations from AAFCO (Association ..., 2003) for growing dogs (Table 1). A 5-d period of adaptation to the diet and to the metabolic cages was applied, followed by five days of total feces collection, as indicated by AAFCO (Association ..., 2003).

No differences were detected between adult dogs and puppies regarding organic matter (OM), dry matter (DM), crude protein (CP), or non-nitrogen extract (NNE) apparent digestibility coefficients (ADC), or energy metabolizability $(\mathrm{P}>0.05)$. However, puppies presented higher acid hydrolysis ether extract ADC $(\mathrm{P}<0.05)$ (Table 2) when compared to adults. 
Table 1. Ingredients and analyzed chemical composition of the experimental diet for adult dogs and puppies

\begin{tabular}{|c|c|c|c|c|}
\hline \multicolumn{2}{|l|}{ Ingredient } & \multicolumn{3}{|c|}{ (\% fresh matter) } \\
\hline \multicolumn{2}{|l|}{ Corn } & \multicolumn{3}{|c|}{59.08} \\
\hline \multicolumn{2}{|l|}{ Poultry offal meal } & \multicolumn{3}{|c|}{26.14} \\
\hline \multicolumn{2}{|l|}{ Corn gluten 60} & \multicolumn{3}{|c|}{5.71} \\
\hline \multicolumn{2}{|l|}{ Poultry fat } & \multicolumn{3}{|c|}{5.00} \\
\hline \multicolumn{2}{|l|}{ Poultry liver hydrolysate } & \multicolumn{3}{|c|}{1.86} \\
\hline \multicolumn{2}{|l|}{ Mineral-vitamin supplement } & \multicolumn{3}{|c|}{1.30} \\
\hline \multicolumn{2}{|l|}{ Salt } & \multicolumn{3}{|c|}{0.71} \\
\hline \multicolumn{2}{|l|}{ Calcium propionate } & \multicolumn{3}{|c|}{0.17} \\
\hline \multicolumn{2}{|l|}{ Potassium sorbate } & \multicolumn{3}{|c|}{0.03} \\
\hline \multicolumn{2}{|l|}{ Total } & \multicolumn{3}{|c|}{100.00} \\
\hline \multicolumn{2}{|l|}{ Chemical composition } & \multicolumn{3}{|c|}{ (\% in dry matter) } \\
\hline \multicolumn{2}{|l|}{ Dry matter (DM) } & \multicolumn{3}{|c|}{90.97} \\
\hline \multicolumn{2}{|l|}{ Crude protein (CP) } & \multicolumn{3}{|c|}{24.62} \\
\hline \multicolumn{2}{|c|}{ Acid hydrolysis ether extract (AEE) } & \multicolumn{3}{|c|}{11.01} \\
\hline \multicolumn{2}{|l|}{ Crude fiber (CF) } & \multicolumn{3}{|c|}{1.35} \\
\hline Mineral matter (MM) & & & 7.00 & \\
\hline Non-nitrogen extract (NNE) ${ }^{1}$ & & & 56.00 & \\
\hline $\mathrm{Ca}$ & & & 1.43 & \\
\hline $\mathrm{P}$ & & & 1.02 & \\
\hline Metabolizable energy (kcal/k & & & $4,020.2$ & \\
\hline $\begin{array}{l}\text { NNE\% }=100-(\mathrm{MM} \%+\mathrm{CP} \%+ \\
\text { Estimated according to the NRC }\end{array}$ & $\begin{array}{l}+\mathrm{CF} \%), \\
t \ldots, 2006\end{array}$ & ter basis. & & \\
\hline Variable & Adult & Puppy & SEM & $P$ \\
\hline Dry matter (\%) & 82.9 & 83.6 & 0.292 & 0.261 \\
\hline Organic matter (\%) & 86.7 & 86.7 & 0.242 & 0.974 \\
\hline Crude protein (\%) & 85.3 & 83.2 & 0.372 & 0.061 \\
\hline $\begin{array}{l}\text { Acid hydrolysis ether extract } \\
\text { (\%) }\end{array}$ & $89.5^{b}$ & $95.3^{\mathrm{a}}$ & 0.927 & $<0.001$ \\
\hline Non-nitrogen extract (\%) & 94.4 & 95.3 & 0.244 & 0.065 \\
\hline $\begin{array}{l}\text { Metabolizable energy } \\
(\mathrm{kcal} / \mathrm{kg})(\%)\end{array}$ & 4,106 & 4,100 & 11.467 & 0.798 \\
\hline
\end{tabular}

Means followed by different letters in the same row are different through the Student's t-test $(\mathrm{P}<0.05)$.

SEM: standard error of the mean.

Puppies have lingual lipase that, together with gastric lipase, aids in the breakdown of milk lipids, making these available for use. During suckling (about four weeks after birth), milk is usually the sole nutrition source for puppies (Iverson et al., 1991). This may explain the higher ether extract digestibility detected in puppies as compared to adults in the present study. Nevertheless, further studies are required to determine for how long lingual lipase remains present and significantly functional in dogs.

In literature, no studies evaluating the same ages used at the present study were found. However, Weber et al. (2003), studying dogs of different breeds and ages (three, five, and nine months, and one year and three months of age), observed higher fat digestibility in dogs older than five months of age as compared to 3-month-old puppies. On the other hand, Swanson et al. (2004) did not find any differences in nutrient digestibility and feces characteristics between 10- and 3-month-old dogs, but observed that 11year-old dogs presented higher dry matter, organic matter, and fat digestibility when compared to 5-month-old puppies. In the Gilham et al. (1993) study, 20-week-old dogs showed higher protein digestibility when compared to 12- and 16-week-old dogs. According to Fahey et al. (2008), both puppies and kittens have lower 
protein digestibility than adults because these present higher pepsin secretion. However, no differences in protein digestibility were found in the present study, consistent with the findings of Taylor et al. (1995).

Gilham et al. (1993), Swanson et al. (2004) and Fahey et al. (2008) suggested that nutrient digestibility improves as the animal ages due to GIT maturation. It is possible that the fermentation of indigestible dietary compounds by the microbiota of puppies may allow them to achieve similar nutrient digestibility as adult dogs. Although ileal digestibility has not been determined, this hypothesis is based in the lower $\mathrm{pH}$ (as measured in dry feces) and the higher ammonia content in the feces of puppies $(\mathrm{P}<0.05)$ (Table 3), which indicate higher fermentation in their intestines.

Table 3. Fecal characteristics of adult dogs and puppies

\begin{tabular}{lcccc}
\hline Parameter & Adult & Puppy & SEM & $P$ \\
\hline Dry matter (\%) & $40.68 \mathrm{~b}$ & $36.63 \mathrm{a}$ & 0.481 & 0.001 \\
Ammonia (\%) & $0.43 \mathrm{a}$ & $0.54 \mathrm{~b}$ & 0.008 & $<0.001$ \\
Fecal score & $3.86 \mathrm{~b}$ & $3.40 \mathrm{a}$ & 0.051 & $<0.001$ \\
gfecFM/kg body weight/day $^{1}$ & 0.44 & 0.43 & 0.011 & 0.890 \\
gfecDM/kg body weight/day $^{2}$ & 0.17 & 0.16 & 0.002 & 0.832 \\
pH fresh feces & 6.37 & 6.29 & 0.032 & 0.962 \\
pH dry feces & $6.05 \mathrm{a}$ & $5.86 \mathrm{~b}$ & 0.021 & $<0.001$ \\
\hline
\end{tabular}

Means followed by different letters in the same row are different through the Student's t-test $(\mathrm{P}<0.05)$. SEM: standard error of the mean.

${ }^{1}$ Feces production on fresh matter (FM) basis (g)/body weight/day.

${ }^{2}$ Feces production on dry matter (DM) basis (g)/body weight/day.

Regarding feces consistency, feces of puppies contained lower dry matter content, and consequently worse fecal score when compared to adult dogs $(\mathrm{P}<0.05)$ (Table 3$)$. The production of wetter feces by puppies may be explained by their higher intestinal transit rate relative to adult dogs, resulting in lower water absorption in the large intestine, as reported by Weber et al. (2003).

Swanson et al. (2004) noted that intestinal microbiota changes as the animal ages, which may influence diet digestilibility, and consequently feces characteristics. However, Benno et al. (1992) comparing the microbiota of the stomach, duodenum, jejunum, or ileum of dogs younger than one year of age and older than eleven, did not find any difference, except for a lower concentration of Clostridium perfringens in the GIT of puppies as compared to elderly dogs. Although in the present experiment no differences were detected in most of the analyzed digestibility parameters, the shorter intestinal transit time associated to a possibly developing intestinal microbiota may explain the different fecal characteristics of puppies, which presented higher moisture and ammonia contents, making their stools softer and with a stronger odor as compared to adult dogs.

Five to six-month-old dogs have higher fat digestibility as compared to five-year-old adult dogs, as well as softer feces with higher ammonia content.

Keywords: Beagle, adult dog, puppy, digestibility

\section{RESUMO}

Os diversos alimentos completos para cães existentes no mercado objetivam atender as necessidades nutricionais do animal quanto ao estádio fisiológico, conforme as alterações que possam ocorrer no aproveitamento dos nutrientes. Com a finalidade de comparar os coeficientes de digestibilidade aparente (CDA) e as características das fezes de um alimento seco extrusado de cães adultos e filhotes, foram utilizados 12 cães da raça Beagle, sendo seis adultos, cinco anos, e seis filhotes, cinco-seis meses, mantidos em gaiolas metabólicas e distribuídos em delineamento inteiramente ao acaso. Os animais 
foram alimentados duas vezes ao dia com um alimento completo seco extrusado para filhotes, por um período de adaptação de cinco dias seguidos por cinco dias de coleta total de fezes. Houve diferença apenas para o CDA do extrato etéreo em hidrólise ácida, sendo maior para os filhotes - 95,3 vs 89,5\%. Em relação às características das fezes, os filhotes apresentaram pior escore fecal, devido às fezes terem se mostrado mais úmidas, além de maior pH em fezes secas e maior teor de amônia, culminando em pior qualidade. Conclui-se que filhotes de 5-6 meses de idade apresentam maior digestibilidade da gordura quando comparado a cães adultos, porém defecam fezes com pior escore fecal.

Palavras-chave: Beagle, cão adulto, cão filhote, digestibilidade

\section{REFERENCES}

ASSOCIATION of American Feed Control Officials, 2003.

BENNO, Y.; NAKAO, H.; UCHIDA, K. et al. Impact of the advances in age on the gastrointestinal microflora of beagle dogs. J. Vet. Med. Sci., v.54, p.703-706, 1992.

FAHEY Jr., G.C.; BARRY, K.A.; SWANSON, K.S. Age-related changes in nutrient utilization by companion animals. Annu. Rev. Nutr., v.28, p.425-445, 2008.

GILHAM M.S.; BOOLES D.; JOHNSON J.V. et al. Digestibility in labrador retrievers during growth. Proc. Nutr. Soc., v.52, p.294, 1993. (Abstr.)

HAYEK, M.G.; DAVENPORT, G.M. Nutrition and aging in companion animals. J. Anti Aging Med., v.1, p.117-123, 1998.

IVERSON, S.J.; KIRK, C.L.; HAMOSH, M. et al. Milk lipid digestion in the neonatal dog: the combined actions of gastric and bile salt stimulated lipases. Biochim. Biophys. Acta Lipids Lipid. Metabol., v.1083, p.109-119, 1991.
MEYER, B.; SPIER, E.; NEUWELT. F. Basal secretion of digestive enzymes in old age. Arch. Intern. Med., v.65, p.171-177, 1940.

NUTRIENT requirements of dogs and cats. Washington: National Academy. 2006. 428p.

SWANSON, K.S.; KUZMUK, K.N.; SCHOOK, L.B. et al. Diet affects nutrient digestibility, hematology, and serum chemistry of senior and weanling dogs. J. Anim. Sci., v.82, p.1713-1724, 2004.

TAYLOR, E.J.; ADAMS, C.; NEVILLE, R. Some nutritional aspects of ageing in dogs and cats. Proc. Nutr. Soc., v.54, p.645-656, 1995.

WEBER, M.; MARTIN, L.; BIOURGE, V. et al. Influence of age and body size on the digestibility of a dry expanded diet in dogs. $J$. Anim. Physiol. Anim. Nutr., v.87, p.21-31, 2003. 